\begin{tabular}{|c|c|c|}
\hline 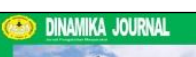 & & \\
\hline 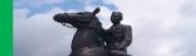 & Dinamika Journal, Vol. 1 No.2, 2019 & \\
\hline$=$ & Journal Homepage : http://jurnal.lppm.unsoed.ac.id/ojs/index.php/dinamika & \\
\hline
\end{tabular}

\title{
TEKNOLOGI OLAHAN MELINJO MENJADI PRODUK MAKANAN AWET BERCITA RASA DAN BERNILAI EKONOMIS TINGGI
}

\author{
Friska Citra Agustia ${ }^{1 *}$, Herastuti Sri Rukmini' ${ }^{2}$, Rumpoko Wicaksono ${ }^{2}$, Rifda Naufalin ${ }^{2}$ \\ ${ }^{1}$ Prodi Ilmu Gizi, Fakultas Ilmu-ilmu Kesehatan, Fakultas Pertanian, Universitas Jenderal \\ Soedirman, Purwokerto \\ ${ }^{2}$ Prodi Ilmu dan Teknologi Pangan, Fakultas Pertanian, Universitas Jenderal Soedirman, \\ Purwokerto \\ *Corresponding author : furissuka@yahoo.co.id
}

Received 5 July 2019; Accepted 25 August 2019; Available online 31 August 2019

\begin{abstract}
Abstrak
Desa Binangun Kabupaten Banyumas merupakan salah satu sentra penghasil melinjo dan produk olahan utama yang diproduksi adalah emping melinjo. IKM Mustika Langgeng Jaya adalah komunitas yang memproduksi emping melinjo dan seriping pisang yang bertujuan untuk meningkatkan kesejahteraan anggotanya. Namun, IKM ini belum mengetahui dan belum menerapkan teknologi olahan berbasis bahan baku lokal, produk yang dihasilkan terbatas pada emping melinjo, kemasan yang digunakan masih sederhana dan belum mencantumkan label sehingga umur simpan pendek dan jangkauan pemasaran rendah. Oleh karena itu diperlukan diversifikasi produk olahan melinjo, perbaikan kemasan dan pelabelan produk serta penerapan manajemen mutu dan keamanan pangan sehingga produk hasil IKM aman dikonsumsi. Program dilakukan dengan metode penyuluhan, pelatihan, praktek demplot atau percontohan serta pendampingan. Kegiatan ini dapat meningkatkan kesejahteraan IKM Mustika Langgeng Jaya.
\end{abstract}

Kata kunci : diversifikasi produk, melinjo, cookies melinjo, Binangun Banyumas

\begin{abstract}
Binangun Village, Banyumas Regency is one of the centers for producing melinjo and the main processed product produced is emping melinjo. IKM Mustika Langgeng Jaya is a community that produces melinjo chips and banana chips which aims to improve the welfare of its members. However, this IKM does not know and has not yet applied processed technology based on local raw materials, the products produced are limited to emping melinjo, the packaging used is still simple and has not included a label so that short shelf life and low marketing reach. Therefore, diversification of melinjo processed products is needed, improvement of product packaging and labeling as well as the application of quality management and food safety so that products from IKM are safe for consumption. The program is carried out using counseling, training,
\end{abstract}


demonstration plot or pilot practices as well as mentoring. This activity can improve the welfare of IKM Mustika Langgeng Jaya.

Keywords: product diversification, melinjo, cookies melinjo, Binangun Banyumas

\section{PENDAHULUAN}

Desa Binangun Kabupaten Banyumas merupakan salah satu sentra penghasil melinjo dan pisang di Kabupaten Banyumas. Produk utama yang dihasilkan adalah emping melinjo dan seriping pisang yang dijual ke area Banyumas dan sekitarnya, desa ini mempunyai potensi cukup besar untuk menggerakkan perekonomian terutama di daerah pedesaan, karena beberapa IKM di desa ini merupakan pemasok melinjo mentah dan emping melinjo yang dijual dalam jumlah besar ke pasar-pasar di Purwokerto dan sekitarnya. IKM di Desa Binangun, sebagian besar merupakan industri skala rumah tangga. Industri kecil menengah ini mempunyai peranan penting, antara lain sebagai salah satu mata pencaharian dan sumber pendapatan masyarakat sekaligus dapat menampung tenaga kerja dan memberikan kesempatan berusaha.

Kelompok Kampung Mandiri OGOP (one grumbul one product) didirikan bertujuan untuk meningkatkan kesejahteraan masyarakat dengan cara membentuk komunitas pengelola potensi unggulan di Desa Binangun. Jumlah mitra yang tergabung dalam kelompok ini adalah 10 mitra potensial yang mulai dirintis dan dibentuk sejak Tahun 2007. IKM Mustika Langgeng Jaya adalah mitra yang secara khusus memproduksi emping melinjo. Melinjo basah sangat mudah rusak dan berjamur karena kadar air yang cukup tinggi. Melinjo dijual dalam bentuk segarnya dengan harga sangat murah yaitu $\mathrm{Rp} 13.000$, dan Rp 40.000 dalam bentuk emping melinjo. Menurut Linda (2013), selain dapat dibuat menjadi emping melinjo juga dapat sebagai bahan pembuatan kerupuk ataupun chips.

Oleh karena itu, perlu dikembangkan diversifikasi olahan melinjo menjadi aneka produk bernilai ekonomis tinggi dan awet. IKM Mustika Langeng Jaya dan Kelompok Kampung Mandiri belum mengetahui potensi dan olahan yang dapat dibuat dari melinjo, serta dalam produksi makanan mereka masih menggunakan kemasan dan pelabelan yang amat sederhana meskipun produksinya dalam jumlah besar. Kondisi tempat produksi juga masih belum sesuai standar operasional proses dan anggota IKM belum mengetahui tentang penjaminan mutu dan keamanan pangan.

Berdasarkan analisis potensi dan daya dukung wilayah, Kelompok Kampung Mandiri dan IKM Mustika Langgeng Jaya berpotensi untuk dijadikan pusat pengembangan dan percontohan agroindustri olahan melinjo di Banyumas.

Pengembangan produksi yaitu memperbanyak produksi, peningkatan kualitas produk contohnya dengan pembuatan aneka olahan melinjo selain menjadi emping melinjo yang merupakan salah satu faktor yang perlu mendapat perhatian, sehingga IKM Mustika Langgeng Jaya dan Kelompok Kampung Mandiri dapat memperoleh pendapatan secara maksimal. Memperbanyak produksi dan peningkatan kualitas perlu dibarengi dengan peningkatan pengetahuan tentang penanganan pengolahan menjadi berbagai produk olahan melinjo sehingga dapat meningkatkan kesejahteraan anggota IKM.

Tujuan Iptek Bagi Masyarakat ini adalah untuk membuat berbagai olahan pangan berbasis melinjo, dengan kemasan menarik dan informatif sehingga akan meningkatkan nilai jualnya. 


\section{METODE}

\section{Lokasi yang Digunakan}

Kegiatan ini dilaksanakan selama 8 bulan di IKM Mustika Langgeng Jaya Desa Binangun Kabupaten Banyumas.

\section{Metode Kegiatan}

Metode yang digunakan dalam kegiatan ini adalah melakukan pembinaan dengan teknik penyuluhan dan pelatihan tentang aneka olahan berbasis melinjo dalam rangka mendukung pencapaian ketahanan pangan . Penyuluhan dan pelatihan meliputi :

Meningkatkan pengetahuan melalui:

- Ceramah tentang manfaat dan cara olahan

- Diskusi dengan khalayak sasaran tentang pentingnya olahan pangan berbasis melinjo

Meningkatkan ketrampilan melalui :

- Pembuatan demplot atau percontohan tentang olahan pangan berbasis melinjo

- Diskusi setelah pembuatan demplot sehingga khalayak sasaran memahami dan mengetahui cara olahan

\section{Khalayak Sasaran}

Dalam aplikasi dan sosialisasi pengolahan produk makanan berbasis melinjo memiliki dua mitra yaitu kelompok IKM Mustika Langgeng Jaya dan Kelompok Komunitas Kampung Mandiri OGOP yang mampu dan mau sebagai kader dan dapat mentransfer hasil kegiatan kepada seluruh IKM olahan pangan yang ada di Desa Binangunl dan sekitarnya.

Adanya kader ini akan memudahkan koordinasi dalam transfer teknologi dari lembaga ilmiah (Perguruan Tinggi) ke masyarakat. Kader ini akan membina di seluruh anggota kelompok tani, sehingga terbina pada khalayak yang lebih luas.

\section{HASIL DAN PEMBAHASAN}

Agro-industri merupakan sektor yang sangat penting di Indonesia, karena sebagian besar masyarakat hidup dari kegiatan usaha yang berkaitan dengan pertanian. Selain itu tidak kalah pentingnya agro-industri menyangkut kebutuhan hidup sehari-hari umat manusia yaitu pangan. Kekurangan pangan dalam jumlah dan mutu yang memadai akan menyebabkan manusia mengalami pengaruh negatif, mulai dari menurunnya produktivitas kerja, kelaparan dan timbulnya berbagai penyakit.

Teknologi diversifikasi aneka makanan berbasis melinjo dapat diterapkan pada para anggota IKM Mustika Langgeng Jaya dan Komunitas Kampung Mandiri Pangan di sekitar Desa Binangun, sehingga mereka mendapatkan informasi tentang teknik pengolahan berbagai produk olahan pangan berbasis melinjo yang lebih menarik dan diminati oleh konsumen.

Penerapan teknologi pembuatan produk pangan yang berpotensi dan pengembangan produk awetan dan diversifikasi berbahan dasar melinjo memiliki tantangan yang harus dihadapi dalam usaha pengembangannya yaitu harganya relatif mahal, produk-produknya yang hingga saat ini cenderung konvensional, nilai gizi kurang lengkap dan penyajian yang kurang menarik. Hal ini menyebabkan relatif rendahnya ketertarikan masyarakat untuk memanfaatkannya. 
Pengembangan produk dari melinjo selain emping, diantaranya menjadi produk tepung melinjo yang dapat digunakan sebagai bahan baku pembuatan aneka kue lainnya, cookies melinjo, kerupuk melinjo dan enting-enting melinjo sehingga dapat meningkatkan nilai ekonomisnya (Desrosier, 1988). Demikian juga dapat memper-panjang umur simpan dan menjadi produk praktis, awet dan dapat sebagai produk oleh-oleh.

Kerupuk melinjo adalah salah satu produk unggulan yang disukai. kerupuk melinjo dibuat dalam bentuk setengah jadi dan yang siap santap (sudah digoreng). Penggorengan kerupuk melinjo menggunakan bahan yang dapat mengabsorpsi minyak dan menggunakan cara penggorengan yang tepat (Fellows, 1990). Bahan tambahan yang biasanya ditambahkan dalam pembuatan kerupuk antara lain garam, bumbu dan bahan pengembang (Nurhayati, 2007). Penambahan garam pada konsentrasi tertentu berfungsi sebagai penambah cita rasa pada pangan (Soeparno, 1995), sedangkan bumbu berfungsi untuk memperbaiki dan menambah cita rasa (Djumali et al., 1982). Kendala yang masih ditemui pada produk kerupuk adalah masalah pengeringan. Menurut Soemarmo (2005), semakin banyak kerupuk mengandung air maka kerenyahannya semakin berkurang.

Produk-produk diversifikasi dan olahan menjadi awetan ini akan mendapat perhatian dari masyarakat dan menarik untuk disajikan, meningkatkan kesejahteraan petani, dan membuka lapangan kerja baru. Upaya diversifikasi produk pangan sekaligus produk awetan akan memberikan nilai unggul dalam upaya pengembangan produk hortikultura seperti melinjo.

Masyarakat Binangun, banyak yang menanam melinjo. Namun mereka hanya menjual dalam bentuk segar dengan harga yang murah dan apabila tidak terjual dalam waktu beberapa hari cepat mengalami kerusakan. Melalui penyuluhan dan pelatihan pembuatan produk olahan awet dan diversifikasi produk dari hortikultura terutama melinjo, mereka sangat antusias untuk mengetahuinya. Pembuatan menjadi produk olahan pangan berbasis melinjo dilakukan dalam beberapa tahapan.

Tahap awal yaitu dilakukan pretest yang bertujuan mengetahui pengetahuan khalayak sasaran sebelum dilakukan penyuluhan.

Penyuluhan dilakukan di Rumah Ketua IKM Mustika Langgeng Jaya yaitu ibu Tarwen dan diikuti sekitar 20 peserta (IKM makanan dan Kelompok Kampung Mandiri) (Gambar 1 dan 2).

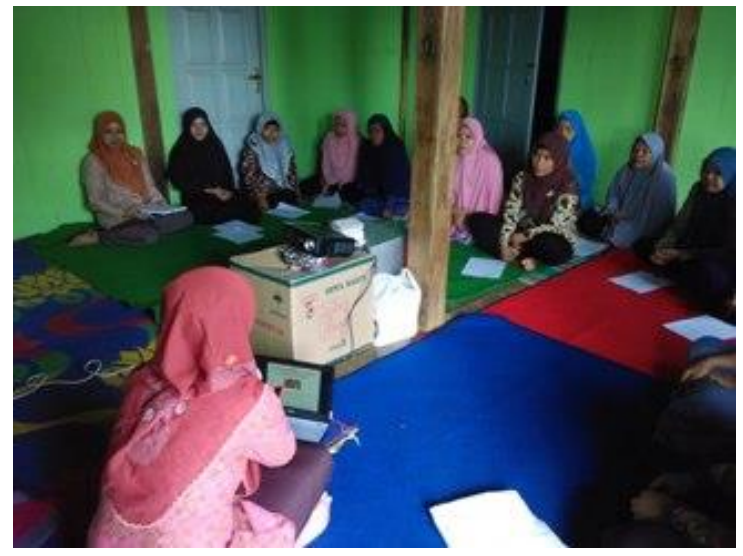

Gambar 1. Penyuluhan tentang Pengolahan Produk Olahan Berbasis Melinjo 


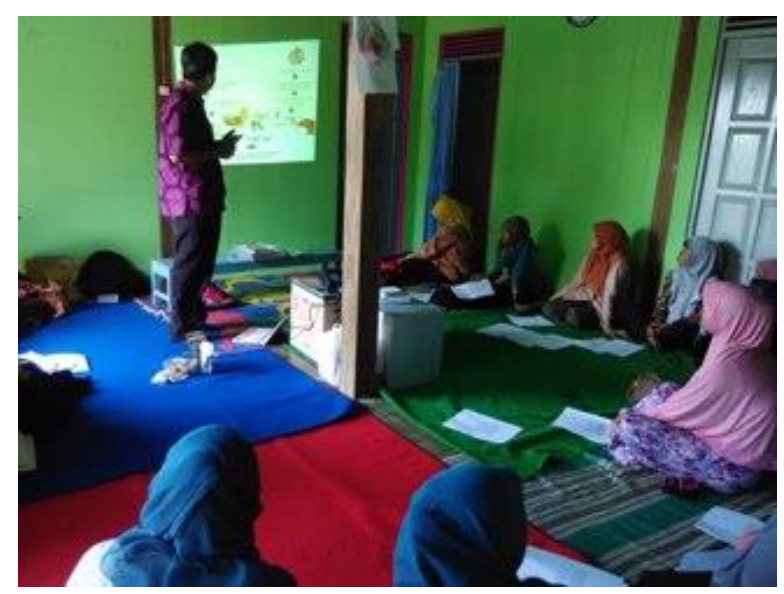

Gambar 2. Penyuluhan tentang pemberdayaan usaha mikro dan teknik pemasaran produk

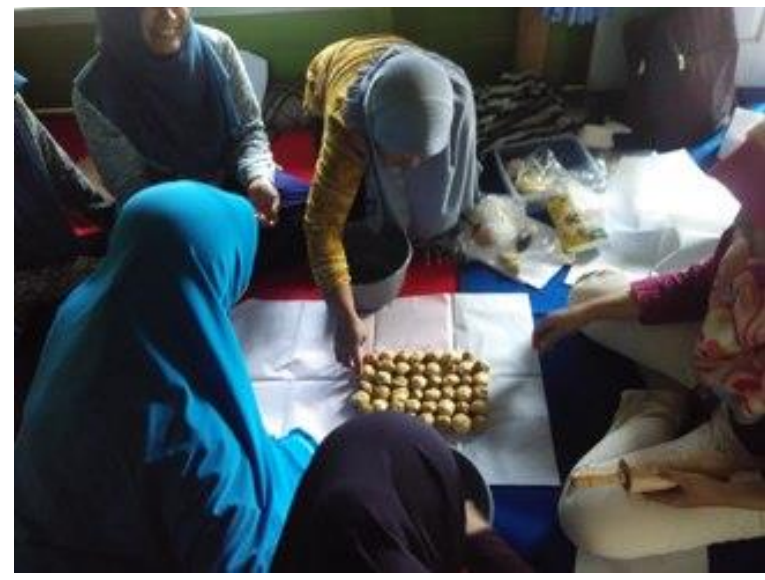

Gambar 3. Praktek pembuatan aneka produk berbasis melinjo (Cookies Melinjo)

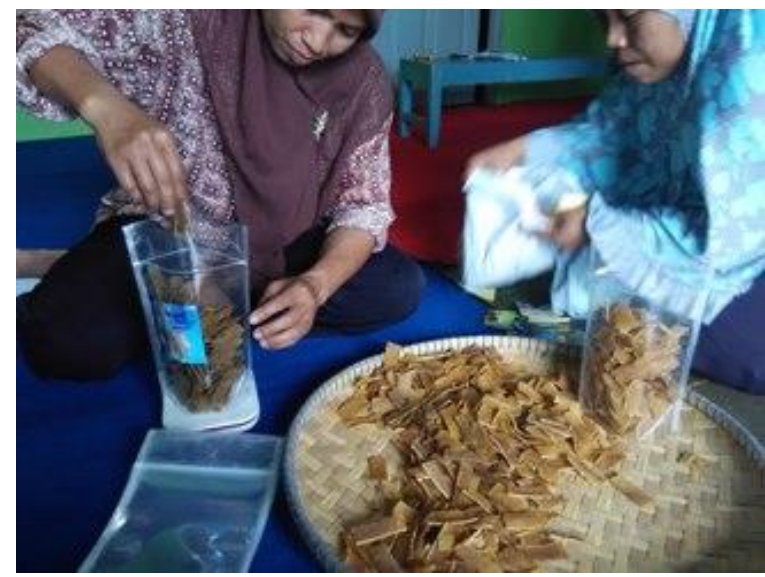

Gambar 4. Praktek pembuatan aneka produk berbasis melinjo (Kerupuk melinjo)

Penyuluhan berupa Teknologi Pengolahan dan Diversifikasi Melinjo menjadi berbagai produk pangan disampaikan oleh Prof. Dr. Rifda Naufalin SP., Msi., yaitu mengolah produk melinjo menjadi produk-produk pangan yang aman, sehat, bergizi, dan memiliki daya tarik bagi 
konsumen. Dengan pengolahan yang tepat dan praktek modern pada preparasi melinjo sehingga olahannya dapat didistribusikan dalam jarak jauh, juga memiliki masa simpan tinggi.

Penyuluhan berupa nilai gizi, daya simpan dan kerusakan melinjo disampaikan oleh Friska Citra Agustia. Melinjo kaya akan protein dan mineral seperti natrium dan kalium yang penting untuk tubuh, melinjo juga sangat baik untuk pencernaan karena mengandung serat tinggi. Banyaknya keunggulan melinjo menyebabkan image melinjo sebagai penyebab asam urat dapat diminimalkan

Penyuluhan lain mengenai pembuatan tepung melinjo sebagai bahan utama kerupuk, chips dan enting-enting melinjo disampaikan oleh Prof. Dr. Herastuti, SR, MS yaitu mengolah melinjo yang biasa diproduksi sehari-hari oleh IKM menjadi produk baru yang familiar dan disukai masyarakat seperti kerupuk dan enting-enting.

Resep-resep olahan pangan berbasis melinjo selanjutnya dipraktekkan oleh IKM Mustika Langgeng Jaya dan Kelompok Kampung Mandiri. Gambar 3. Menunjukkan praktek pembuatan olahan melinjo menjadi produk cookies melinjo, sedangkan Gambar 4 menunjukkan praktek pembuatan olahan melinjo menjadi kerupuk melinjo. Dengan penggunaan bahan local (tepung melinjo) ini akan mendukung ketahanan pangan. Anggota IKM Mustika Langgeng Jaya sebagai mitra dapat dilihat pada Gambar 5.

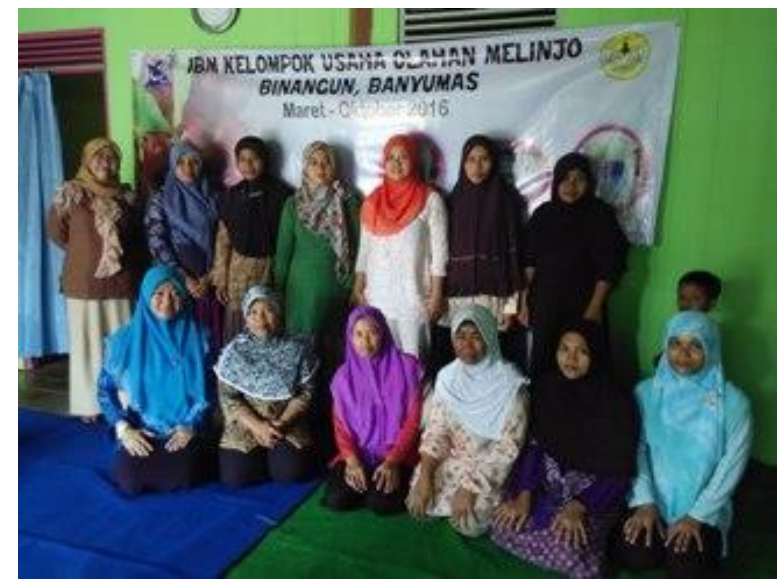

Gambar 5. Anggota IKM Mustika Langgeng Jaya

Permasalahan ketahanan pangan terkait dengan konsumsi pangan. Pemenuhan kebutuhan pangan merupakan hal yang sangat penting untuk diwujudkan baik dari sisi sosial maupun moral. Sesuai dengan Undang-undang Nomor 7 Tahun 1996 tentang Pangan, ketahanan pangan terwujud apabila seluruh penduduk mempunyai akses fisik dan ekonomi terhadap pangan untuk memenuhi kecukupan nutrisi sesuai kebutuhannya agar dapat menjalani kehidupan. Hal ini berarti ketahanan pangan diartikan sebagai suatu kondisi terpenuhinya pangan yang cukup dalam jumlah maupun mutunya, merata dan terjangkau oleh daya beli masyarakat.

Kegiatan pelatihan untuk mendukung pemenuhan kebutuhan pangan yang cukup dalam jumlah, bergizi, bermutu serta terjangkau oleh daya beli masyarakat dapat dilakukan melalui diversifikasi pangan. Oleh karenanya, perlu upaya serius melakukan diversifikasi pangan seiring dengan bertambahnya jumlah penduduk dan berkurangnya lahan pertanian. Oleh karena itu, perlu pengembangan produk baru berbahan dasar lokal misalnya produk olahan melinjo. Produk 
unggulan yang diproduksi salah satunya adalah kerupuk melinjo dan cookies melinjo (Gambar 5 dan 6).

Penyuluhan selanjutnya tentang pengemasan dan pelabelan produk disampaikan oleh Riana Listanti, S.TP, M.Sc. Produk hasil olahan perlu dikemas agar terlindung dari berbagai faktor penyebab kerusakan.Kecuali itu, pengemasan juga dapat berfungsi untuk memberikan Informasi dan promosi kepada konsumen, mengenai produk yang ada dalam kemasan. Pengemasan yang baik dan disertai dengan labelling, akan meningkatkan daya saing produk di pasar. Produk olahan melinjo produksi IKM diperbaiki kemasannya dan dikemas menarik disertai label yang informatif sehingga akan memperpanjang umur simpannya, memperluas jangkauan pemasaran dan meningkatkan nilai ekonomisnya.

Penyuluhan mengenai manajemen mutu dan keamanan pangan disampaikan oleh Prof. Dr. Rifda Naufalin, M.Si. Lokasi produksi makanan ringan masih belum memenuhi standar hygiene dan sanitasi serta belum memiliki standar operasional proses sehingga hasil produksinya masih belum terstandar. Dengan adanya penyuluhan ini, anggota IKM mulai membenahi lokasi produksi dan menerapkan hygiene dan sanitasi makanan sehingga produknya menjadi bermutu tinggi dan aman untuk dikonsumsi.

Penyuluhan terakhir mengenai pemberdayaan usaha mikro kecil menengah dan teknik pemasaran disampaikan oleh Dr. Rumpoko Wicaksono, SP, MP. Strategi kerjasama dengan pihak-pihak bidang permodalan, pengembangan dan peningkatan mutu produk serta pendampingan pengelolaan usaha disampaikan agar IKM yang ada semakin kokoh. Teknik pemasaran dengan berbagai sosial media seperti instagram, group whattshap dan penjualan online menambah wawasan anggota IKM untuk mulai mencoba teknik pemasaran baru yang mudah dan murah ini.

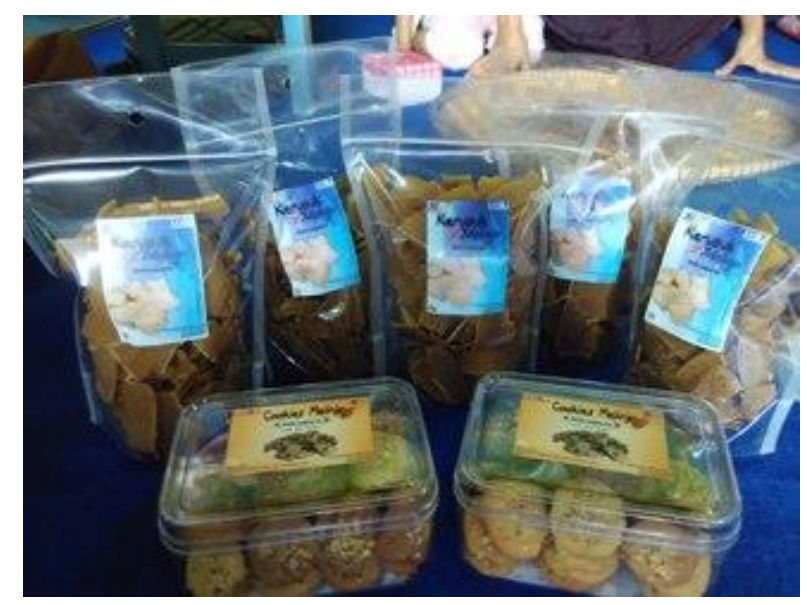

Gambar 6. Produk olahan berbasis melinjo (kerupuk dan cookies melinjo) 


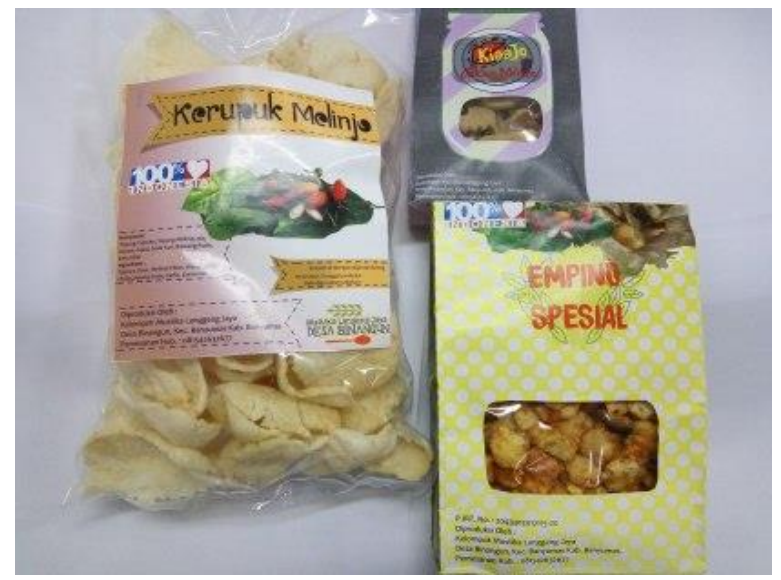

Gambar 7. Produk unggulan olahan berbasis melinjo

\section{KESIMPULAN DAN SARAN}

\section{Kesimpulan}

Berdasarkan hasil pembuatan produk olahan berbasis melinjo serta hasil monitoring akhir respon khalayak sasaran terhadap produk yang dihasilkan, dapat diambil kesimpulan bahwa masyarakat Desa Binangun terutama anggota IKM Mustika Langggeng Jaya dan Kelompok Kampung Mandiri Kabupaten Banyumas menerima sekaligus dapat mempraktekkan aneka produk olahan melinjo dengan hasil memuaskan. Hal ini ditunjukkan, adanya perbedaan sangat nyata antara nilai pre-test dan post-test pada khalayak sasaran dengan persentase kenaikan nilai sebesar $87,7 \%$.

\section{Saran}

Mengacu pada respon masyarakat Desa Binangun Kabupaten Banyumas terhadap keberhasilan teknik diversifikasi olahan berbasis melinjo, diperlukan adanya dukungan dari Pemerintah Daerah (PEMDA) dan Dinas Perindustrian setempat untuk pembinaan lebih lanjut. Perlu adanya pengkajian dari sisi ekonomi terhadap keunggulan produk.

\section{DAFTAR PUSTAKA}

Badan Standardisasi Nasional. 1992. SNI 01-2986-1992.

Buckle, K. A. 1987. Ilmu Pangan. Terjemahan: Hari Purnomo dan Adiono. Penerbit Universitas Indonesia. Jakarta. 365 hal.

Desrosier, N. W. 1988. Teknologi Pengawetan Pangan. UI-Press. Jakarta.

Djumali, Z., I. Nasution, Sailah., M. S. Ma'arif. 1982. Teknologi Kerupuk. Buku Pegangan Petugas Lapang Penyebarluasan Teknologi Sistem Padat Karya. FATEMATETA-IPB. Bogor.

Fellow, P. J. 1990. Food Processing Technology. Ellis Horwood, New York. 505 pp. 
Linda, Y. 2013. Potensi dan Peluang Pengembangan Teknologi Pengolahan Melinjo dalam Mendukung Ketahanan Pangan di Provinsi Jambi. Laporan Penelitian. Balai Pengkajian Teknologi Pertanian Jambi.

Nurhayati, A., K. Ummah., S. Tjahjani. 2007. Sifat Kimia Kerupuk Goreng yang diberi Penambahan Tepung Daging Sapid an Perubahan Bilangan TBA selama Penyimpanan. Skripsi. Fakultas Pertanian, Institut Pertanian Bogor, Bogor.

Soeparno. 2005. Ilmu dan Teknologi Daging. Gadjah Mada University Press.Yogyakarta.346 hal.

Soemarmo. 2005. Kerupuk Udang. Fakultas Teknologi Pertanian. Institut Pertanian Bogor, Bogor

Winarno, F.G. 1980. Pengantar Teknologi Pangan. PT. Gramedia. Jakarta.

Winarno, F. G. 2002. Kimia Pangan dan Gizi.Penerbit PT Gramedia Pustaka utama. Jakarta.253 hal. 